\title{
SISTEM INFORMASI DAN PEMBELAJARAN BATIK MENGGUNAKAN METODE BLENDED LEARNING BERBASIS ANDROID
}

\author{
Reynaldi Putra Widia Hardi ${ }^{1}$, Yesua ${ }^{2}$, Yudha Praditya Gani ${ }^{3}$, Tazkiyah Herdi $^{4}$ \\ 1,2,3 Jurusan Sistem Informasi Fakultas Ilmu Komputer Universitas MercuBuana \\ Jl. Meruya Selatan No.1 - Kembangan Jakarta Barat 11650 \\ 141818210019@student.mercubuana.ac.id \\ 241818210023@student.mercubuana.ac.id \\ 341818210001@student.mercubuana.ac.id \\ 4tazkiyah.herdi@mercubuana.ac.id
}

\begin{abstract}
Abstrak
Model blended learning merupakan kegiatan pembelajaran yang mengkombinasikan kegiatan tatap muka dan daring. Dalam penerapannya pembelajaran ini mengurangi pembelajaran secara langsung di kelas, apalagi dimasa pandemi COVID-19 ini semua sektor dari kantor hingga pendidikan bahkan semua unsur diharuskan untuk memanfaatkan teknologi untuk mengurangi sebaran virus. Batik adalah produk kesenian Indonesia yang banyak disukai oleh banyak negara. Sampai sekarang, batik dikenal sebagai salah satu karya yang sudah menjadi kebanggaan negara Indonesia. Rumah Batik Palbatu selama pandemi mengharuskan kegiatan pembejalaran harus dihentikan sementara. Tidak hanya kegiatan pembelajaran, kegiatan acara-acara yang diselenggarakan oleh Rumah Batik Palbatu pun terkena dampaknya. Penelitian ini bertujuan untuk membuat rancangan aplikasi pembelajaran batik dengan dua proses bisnis inti yaitu pembelajaran daring dan luring. Wawancara dengan pihak terkait, observasi dan studi dokumen dilakukan untuk mendapatkan gambaran permasalahan, proses bisnis berjalan dan analisis kebutuhan yang digambarkan dengan rich picture, dan Business Process Modellling Notation (BPMN). Hasil analisis dikembangkan dengan prototyping yang digambarkan menggunakan diagram UML.
\end{abstract}

Kata kunci: Batik, Rumah Batik Palbatu, Aplikasi, Prototype, Pembelajaran.

\section{Pendahuluan}

Model blended learning merupakan kegiatan pembelajaran yang mengkombinasikan kegiatan tatap muka dan daring. Dalam penerapannya pembelajaran ini mengurangi pembelajaran secara langsung di kelas, apalagi dimasa pandemic Covid 19 ini semua sektor dari kantor hingga pendidikan bahkan semua unsur terpaksa unttuk melakukan sistem tatap muka daring, dengan adanya model blended learning semuanya bisa berjalan, walaupun tidak seperti biasanya ketika di lakukannya luring. Tujuan pembelajaran blended adalah membuat siswa lebih aktif dan mandiri dalam belajar. Kelebihan dari model blended learning adalah dapat digunakan menyampaikan materi belajar dimana dan kapan saja, pembelajaran terjadi secara daring maupun luring yang saling melengkapi, pembelajaran menjadi efektif dan efesian, meningkatkan aksesbilitas, dan pembelajaran menjadi luwes dan tidak kaku. Model pembelajaran blended learning dengan berbantuan aplikasi google classroom digunakan sebagai alat bantu yang berfungsi melancarkan jalannya kegiatan belajarmengajar. [1]

Depdiknas juga intensif mendorong pengembangan elearning untuk memberikan layanan dan kesempatan pada masyarakat luas yang selama ini tidak terjangkau dengan sistem konvensional secara tatap muka. Se- hingga dengan adanya model e-learning ini memungkinkan untuk men- capai sasaran yang lebih luas di seluruh Indonesia (to reach the unreached). [2]

Batik merupakan salah satu jenis kerajinan yang telah berkembang pesat di Jawa sejak beberapa ratus tahun yang lalu. Batik dapat diartikan sebagai menulis di atas kain dengan menggunakan alat canting dan memakai bahan lilin yang disebut rengrengan dan apabila telah selesai dibatik diberi warna. Dengan demikian, batik adalah gambaran di atas kain dengan menggunakan lilin sebagai bahan pencegah meresapnya warna yang tidak dikehendaki ke dalam kain. Alat yang digunakan adalah canting atau cap, kemudian dicelup ke dalam larutan yang telah diberi warna. [3] 
Penelitian terkait pembelajaran daring telah dilakukan oleh beberapa peneliti dari berbagai perspektif, antara lain:

Penelitian oleh Purwanto S.K \& Suharno Pawirosumarto (2017). Menekankan bahwa e-learning haruslah menggunakan internet yang bersifat online yaitu komputer yang terhubung dengan internet. Dapat diartikan bahwa pembelajar dalam mengakses materi pembelajaran tidak terbatas jarak, ruang dan waktu, bisa dimana saja dan kapan saja. [4] Penelitian oleh Anita Ratnasari (2012). ELearning mempermudah interaksi antara mahasiswa dengan bahan atau materi pelajaran. Kesiapan sistem e-learning, dukungan dari dosen dan juga dari sesama mahasiswa dalam proses kegiatan belajar mengajar dengan memberikan umpan balik dari forum dan kuis. [5]

Penelitian oleh Emria Fitri, Neviyarni, Ifdil (2016). Dalam jurnal yang berjudul "Efektivitas layanan informasi dengan menggunakan metode blended learning untuk meningkatkan motivasi belajar" menjelaskan tentang pembelajaran menggunakkan metode offline dan online yang bertujuan agar memotivasi dalam pembelajaran. Dari hasil penelitian penulis bahwa layanan informasi dengan menggunakan metode blended learning untuk meningkatkan motivasi belajar siswa dan akan terlaksana secara intensif, bila terprogram secara terpadu dengan program bimbingan dan konseling. [6] Dalam penelitian lainnya mengatakan bahwa pembelajaran menggunakkan metode blended learning memicu kemandirian dalam proses pembelajaran yang dituliskan oleh Tsuwaybah Al Aslamiyah, Punaji Setyosari, Henry Praherdhiono (2019). [7] Salah satunya melakukan penelitian inovasi pembelajaran membatik Indonesia dan Malaysia oleh Farid Abdullah, Dewi M. Sya'bani, Bandi Sobandi, Bambang Tri Wardoyo, Badrul Isa, Sumardianshah Silah (2021). Mengatakan bahwa inovasi pembelajaran membatik di era masyarakat 5.0 dengan menerapkan metode pembelajaran blended learning yang lebih efektif dan sesuai dengan kemajuan transformasi digital pada saat ini. [8] Penelitian oleh Agus Akhmadi (2021). Penulis melakukan penelitian terhadap penerapan blended learning dalam pelatihan yang dapat diterapkan sebagai salah satu model pelatihan pada lembaga kediklatan. Untuk optimalisasi blended learning dalam pelatihan diperlukan dukung sarana prasarana teknologi informatika yang memadai dan kemandirian peserta. [9] Dengan adanya pelatihan online dapat membantu users dalam melaksanakan kegiatan pelatihan dengan memberikan suatu aplikasi pembelajaran melalui website, penelitian oleh Alif Yusriyanto, Zainul Arham, Nuryasin (2018). Aplikasi pelatihan online ini belum memaksimalkan kegiatan pelaksanaan pelatihan dengan penjadwalan dan komunikasi. [10]

Penelitian diatas merupakan penelitian terkait yang digunakan untuk menyelesaikan penelitian ini. Namun dari penelitian diatas belum ada yang membahas mengenai Sistem Pembelajaran Membatik dengan metode pelatihan gabungan antara Luring dan Daring berbasis Aplikasi Android.

Rumah Batik Palbatu adalah merupakan salah satu swadaya dan tempat pelatihan batik yang berada di Jakarta. Proses pelatihan batik di Rumah Batik Palbatu ini dengan cara tradisional. Peserta dapat megikuti pelatihan membatik di Rumah Batik Palbatu ini dengan datang ke tempat pelatihan. Dengan adanya pandemi COVID-19 dan pemerintah melakukan kebijakan pembatasan kegiatan masyarakat, Rumah Batik Palbatu tidak dapat mengandalkan proses bisnis sebelumnya untuk dapat beradaptasi dengan normal yang baru.

Berdasarkan latar belakang diatas, penulis melakukan wawancara, observasi dan studi literatur untuk mengetahui sistem berjalan dan analisis kebutuhan pada Rumah Batik Palbatu. Hasil analisis dikembangkan dengan prototyping yang digambarkan menggunakan diagram UML.

\section{Metodologi PenElitian}

\subsection{Metode Pengumpulan Data}

Pengumpulan data dilakukan dengan cara mempelajari sistem pembelajaran yang berjalan saat ini. Penulis melakukan wawancara dengan Rumah Batik Palbatu, observasi dan studi dokumen yang di jadikan objek pembelajaran dan laporan yang di hasilkan dari pembelajaran tersebut.

\subsection{Analisis Data}

Pengambilan data menggunakan lembar ceklist berdasarkan observasi yang dilakukan. Hal ini bertujuan untuk memperoleh data primer agar semua data yang diperlukan tidak ada yang terlewatkan. Selain itu, dilakukan penelitian kepustakaan untuk memperoleh data sekunder yang mendukung penelitian ini seperti jurnal dan buku sebagai bahan rujukan dalam mencari, mengumpulkan, dan mempelajari informasi informasi yang berkaitan dengan sistem pembelajaran membatik yang mendukung pembuatan sistem informasi yang menerapkan teknologi berbasis web.

\subsection{Metode Pembangunan Sistem}

Sistem ini dibuat dengan menggunakkan metodologi SDLC atau yang dikenal dengan Software Development Life Cycle. Salah satu model SDLC yang paling sering digunakan untuk menggambarkan proses dari pengembangan software adalah model Prototype. Metode pengembangan sistem Prototype adalah sebuah bentuk dalam melakukan tahap analisis, desain, dan implementasi secara bersamaan dan dilakukan berulang ulang dalam satu siklus sampai sebuah sistem selesai. [11] Metode Prototype sangat tepat digunakan dalam sebuah project yang memiliki kriteria kebutuhan penggunannya masih belum jelas dan memiliki waktu pengembangan yang sangat singkat. Penelitian terbagi menjadi beberapa tahapan seperti Gambar 1.

Berikut ini penjelasan masing masing tahapan yang di lakukan dalam penelitian :

\section{Evaluasi Prototype}

Pada tahap ini merupakan pemeriksaan atau mengevaluasi dari desain prototype yang sudah dibuat, 
jika ada yang kurang tepat dari desain prototype, kami harus kembali ke awal dalam menganalisis kebutuhan.

2. Evaluasi Sistem

Pada tahap ini pengguna melakukan evaluasi apakah perangkat lunak sudah sesuai dengan apa yang diharapkan atau tidak. Jika ya, lakukan tahap selanjutnya. Jika tidak, ulangi tahap mengkodekan sistem dan pengujian sistem.

3. Menggunakan Sistem

Pada tahap ini merupakan tahap akhir metode Prototyping yaitu perangkat lunak yang telah diuji dan disetujui siap untuk digunakan.

\section{HASIL DAN PEMBAHASAN}

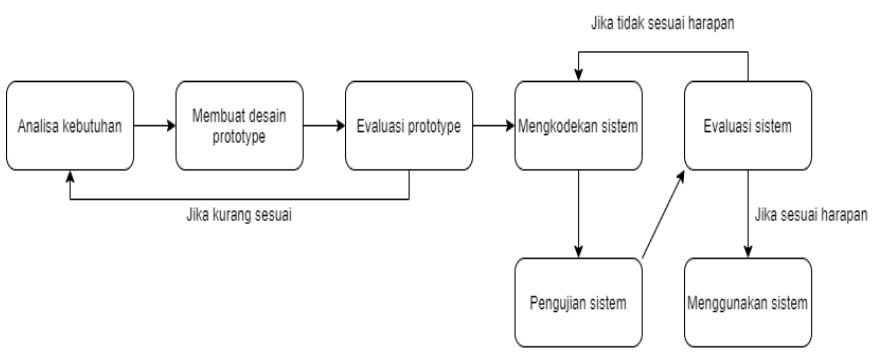

Gambar 1. Metode SDLC Prototyping

Pada Gambar 1 dapat di jelaskan bahwa :

1. Analisis Kebutuhan

Pada tahap ini merupakan awal pengembang melakukan identifikasi perangkat lunak dan semua kebutuhan sistem yang akan dibuat. Disini kami akan menyelesaikan semua kebutuhan yang di perlukan.

2. Membuat Desain Prototype

Pada tahap ini merupakan awalan dalam membuat desain prototype yang dibutuhkan setelah menganalisis kebutuhan sistem yang ada.

3. Evaluasi Prototype

Pada tahap ini merupakan pemeriksaan atau mengevaluasi dari desain prototype yang sudah dibuat, jika ada yang kurang tepat dari desain prototype, kami harus kembali ke awal dalam menganalisis kebutuhan.

4. Mengkodekan Sistem

Pada tahap ini dilakukan jika prototype disetujui maka akan diterjemahkan ke bahasa pemrograman yang sesuai.

5. Pengujian Sistem

Pada tahap ini dilakukan setelah perangkat lunak sudah siap, selanjutnya akan perangkat lunak harus melewati pengujian.

6. Evaluasi Sistem

Pada tahap ini pengguna melakukan evaluasi apakah perangkat lunak sudah sesuai dengan apa yang diharapkan atau tidak. Jika ya, lakukan tahap selanjutnya. Jika tidak, ulangi tahap mengkodekan sistem dan pengujian sistem.

7. Menggunakan Sistem

Pada tahap ini merupakan tahap akhir metode Prototyping itu perangkat lunak yang telah diuji dan disetujui siap untuk digunakan. [11]

Proses sistem yang berjalan saat ini pada saat melakukan pendaftaran pelatihan membatik dengan cara datang langsung ke tempat pelatihan membatik dan melakukan pembayaran secara langsung setelah itu pihak tempat pelatihan membatik akan melakukan konfirmasi data dan pembayaran kepada peserta membatik, ketika peserta sudah di konfirmasi oleh pihak rumah batik selanjutnya peserta akan diarahkan untuk melakukan pelatihan membatik sesuai jadwal yang sudah di tentukan oleh pihak membatik.

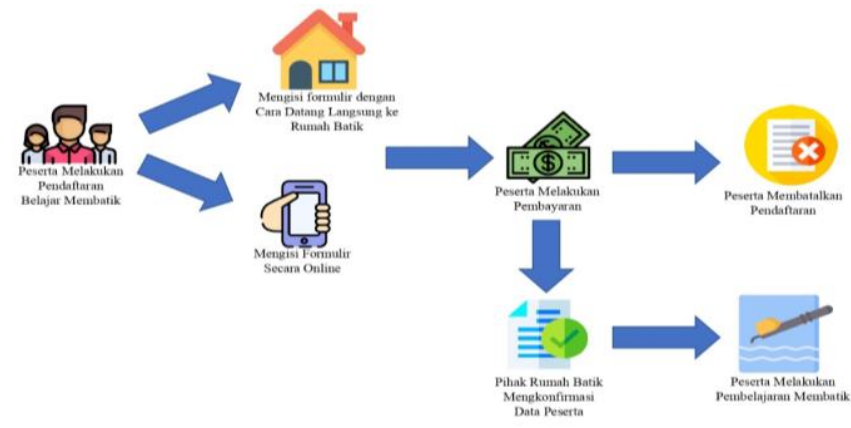

Gambar 2. Rich Picture Proses Bisnis Berjalan

Analisis masalah adalah langkah awal yang diperlukan untuk mengetahui permasalahan apa saja yang terjadi pada sistem yang telah berjalan. Analisis masalah yang dimaksud adalah dimana melakukan pendaftaran pelatihan ini masih harus datang ke tempat pelatihan tersebut, dimana kegiatan itu memakan banyak waktu dan kurang diketahuinya lokasi pelatihan tersebut. Dimasa pandemic sekarang disarankan untuk menghindari pertemuan - pertemuan yang memicu penyebaran Covid-19. Dengan itu semua pendaftaran akan dimasukan ke dalam system.

Berdasarkan hasil dari tahapan identifikasi masalah, maka dapat dilakukan tahap analisis kebutuhan bisnis. Konsep blended learning sebagai kombinasi pembelajaran dari dua model proses belajar-mengaja yaitu antara sistem pembelajaran tradisional sehingga memungkinkan siapapun dapat belajar dimanapun dan kapanpun. Atas hal itu rumah batik PalBatu membutuhkan dua proses bisnis inti yaitu pembelajaran daring dan luring.

Proses pembelajaran luring para peserta pelatihan bisa melakukan pendaftaran menggunakan aplikasi. Setelah melakukan pendaftaran, Peserta dapat datang ketempat membatik dan akan mengikuti pelatihan membatik yang sudah di tentukan oleh pihak rumah batik dan setelah itu peserta juga bisa melakukan pelatihan membatik secara langsung sesuai dengan motif yang diinginkan. 
Proses pembelajaran daring para peserta harus menggunakkan aplikasi untuk mendaftar pelatihan batik, didalam aplikasi tersebut para peserta akan dimudahkan dengan banyak fitur pelatihan dan ujian yang nantinya hasil dari pelatihan dan ujian tersebut bisa menjadi bahan evaluasi para pelatih di rumah batik.

Pada tahap analisis kebutuhan bisnis membutuhkan proses pendaftaran pelatihan membatik, para pengguna aplikasi melakukan pendaftaran untuk mengikuti pelatihan membatik, dengan mengisi data pribadi secara lengkap seperti nama, tempat tanggal lahir, alamat, no hp, dll. Berikutnya system akan menampilkan pembayaran untuk melakukan pelatihan membatik tersebut, lalu system akan menampilkan kelas yang akan di ikuti pengguna aplikasi secara daring ataupun tatap muka jika dibutuhkan.

Sistem usulan proses bisnis pendaftaran course dan pendaftaran event di rumah batik palbatu seperti dibawah ini :

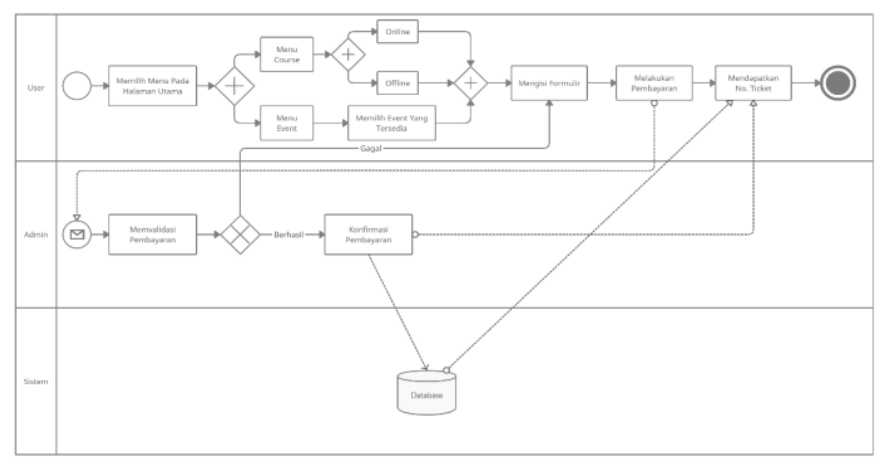

Gambar 3. BPMN Sistem Usulan Pendaftaran Course Event

Pada Gambar 3 dijelaskan bahwa peserta jika ingin melakukan pendaftaran Course atau Event. Untuk course tersedia Course daring dan luring, Setelah peserta memilih pilihan Course dan event yang ingin diikuti Kemudian peserta mengisi formulir dan melakukan pembayaran. Setelah itu admin mengkonfirmasi pembayaran. Setelah melakukan pendaftaran peserta akan mendapatkan tiket acara.

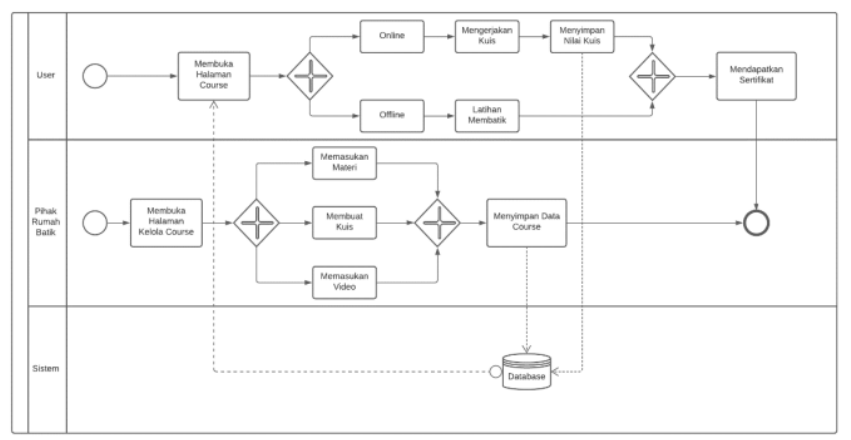

Gambar 4. BPMN Sistem Usulan
Pada Gambar 4 dijelaskan bahwa Pihak Rumah Batik melakukan Kelola Course mulai dari Memasukan Materi, Membuat Kuis, dan memasukan Video, Kemudia Pihak Rumah Batik menyimpan data Course. User dapat membuka Course yang telah mereka bayar. Untuk course daring, user dapat mengerjakan Kuis yang tersedia, kemudian mendapatkan nilai kuis. Untuk course luring, user dapat melakukan latihan membatik di Rumah Batik Palbatu. Setelah User selesai melakukan Course, user akan mendapatkan Sertifkat.

Hasil pengembangan aplikasi sistem informasi pendaftaran belajar membatik digambarkan dalam bentuk Unified Modelling Language ( UML ) dan User Interface ( UI ) design.

Pada Use Case Diagram menggambarkan aktivitas yang dapat dilakukan pengguna sistem dalam aplikasi , antara lain : register, login, pesan course, upload materi, kelola ujian, kelola event, kelola course, kelola info batik, mengerjakan course, melakukan pembayaran, daftar event, pembutan laporan, mengelola pembayaran, seperti terlihat pada Gambar 5 .

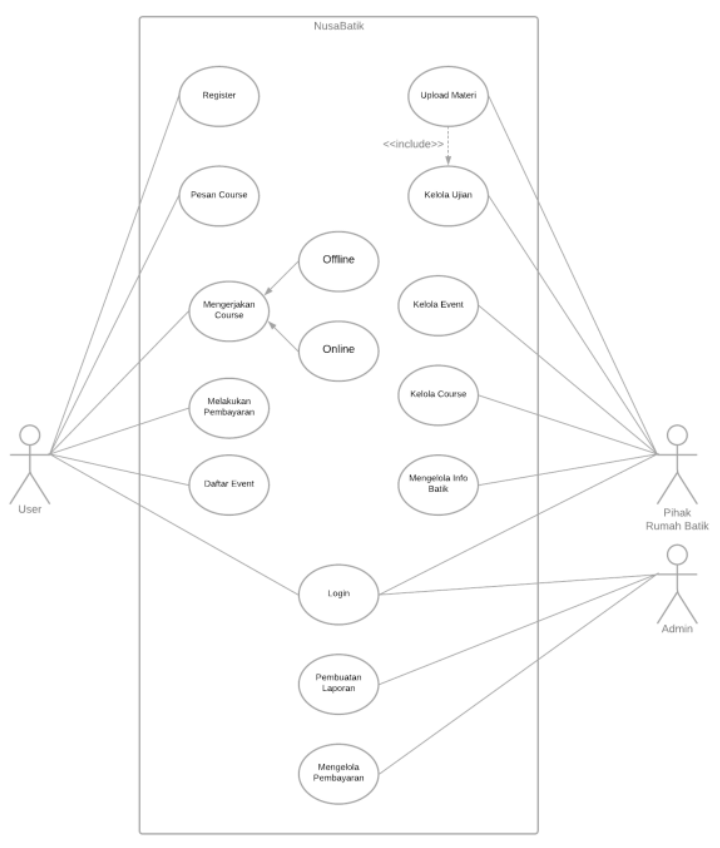

Gambar 5. Use Case Diagram

Berdasarkan aktivitas diatas maka diperlukan struktur data dan class pada aplikasi yang dapat dilihat pada Gambar 6 . Dijelaskan bahwa rancangan dalam membuat class diagram yang merupakan relasi antar class. 


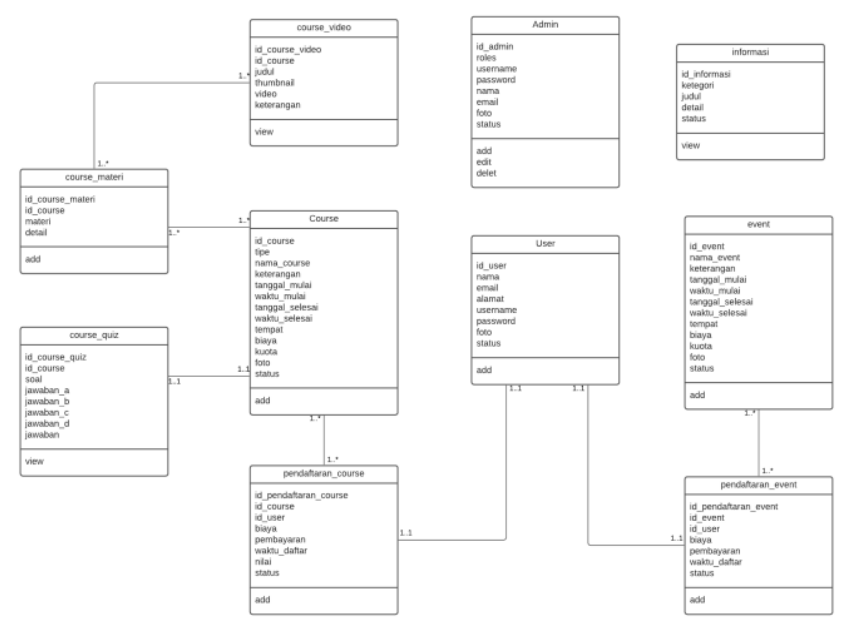

Gambar 6. Class Diagram

Perangkat lunak / software yang dibutuhkan untuk membuat sistem informasi ini adalah menggunakkan sistem operasi Windows, Android, Android Studio, Java Development Kit, WebService, JSON, MySQL. Untuk menjalankan sistem ini menggunakkan Web seperti Google Chrome, Mozilla Firefox dan Android.

Aplikasi ini terdiri dari 2 platform yaitu, menggunakan android untuk user dimana user dapat melakukan pemesanan Course dan Event, dan menggunakan Website untuk admin dimana admin dapat mengelola course dan event.

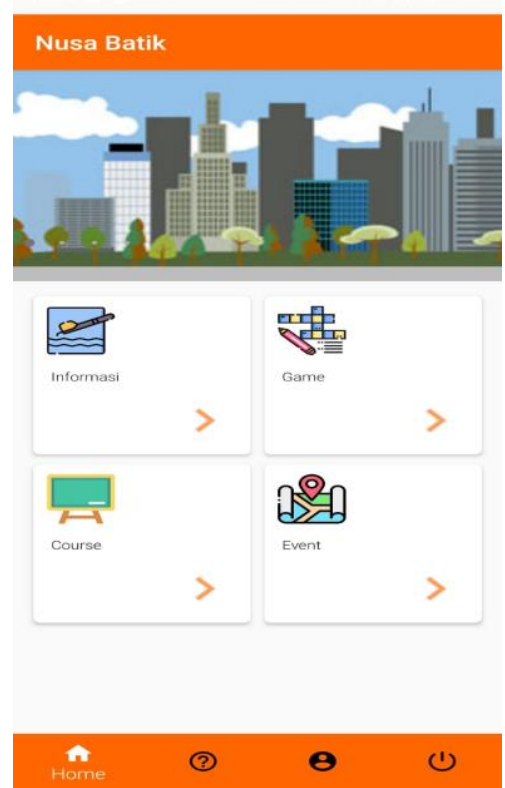

Gambar 7. Halaman Utama Aplikasi NusaBatik

Pada Gambar 7 merupakan Halaman Utama dari Aplikasi NusaBatik yang berisi tentang Informasi, Game, Course, dan Event. Pada halaman ini user dapat membaca informasi tentang batik, memainkan game, melakukan pemesanan Course dan Event.

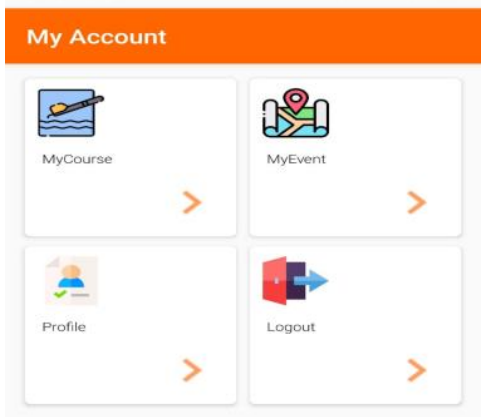

Gambar 8. Halaman Profile Akun Aplikasi NusaBatik

Pada Gambar 8 merupakan tampilan Halaman Profile Akun Aplikasi NusaBatik yang berisi Course, MyEvent, Profile, dan Logout. Pada halaman ini user dapat melihat Course dan event apa saja yang telah dipesan sebelumnya dan juga user dapat merubah profile seperti nama, no telp, dll.

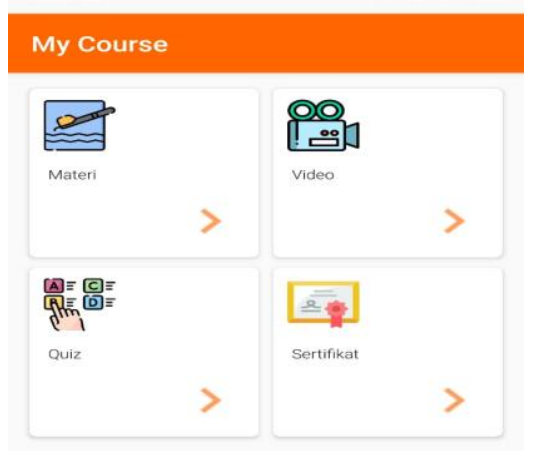


telah dipesan, user dapat membaca materi, menonton video, dan juga dapat mengerjakan Quiz yang dimana setelah mengerjakan Quiz akan mendapatkan Sertifikat.

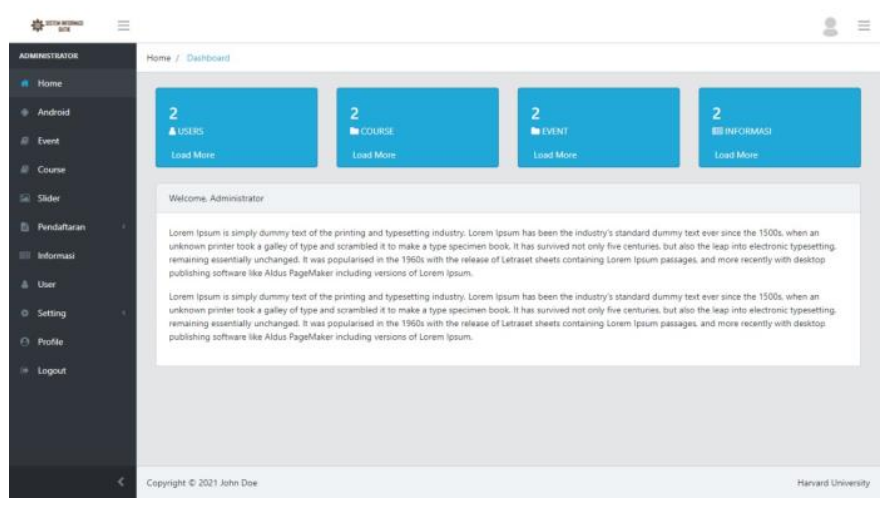

Gambar 10. Halaman Utama Admin Aplikasi NusaBatik via Website

Pada Gambar 10 merupakan tampilan Halaman Utama Admin Aplikasi NusaBatik via yang berisi dashboard tentang user, course, event, informasi. Pada halaman ini admin dapat melihat berapa banyak User, Course, Event, dan Informasi yang terdapat pada aplikasi NusaBatik

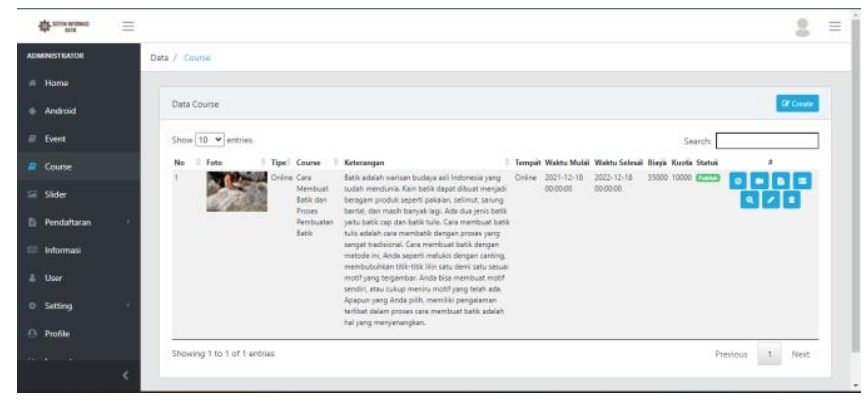

Gambar 11. Halaman Kelola Course Aplikasi NusaBatik via Website

Pada Gambar 11 merupakan tampilan Halaman Kelola Course Aplikasi NusaBatik via Website. Pada halaman ini admin dapat mengelola Course seperti menambah, menghapus, dan mengedit data Course.

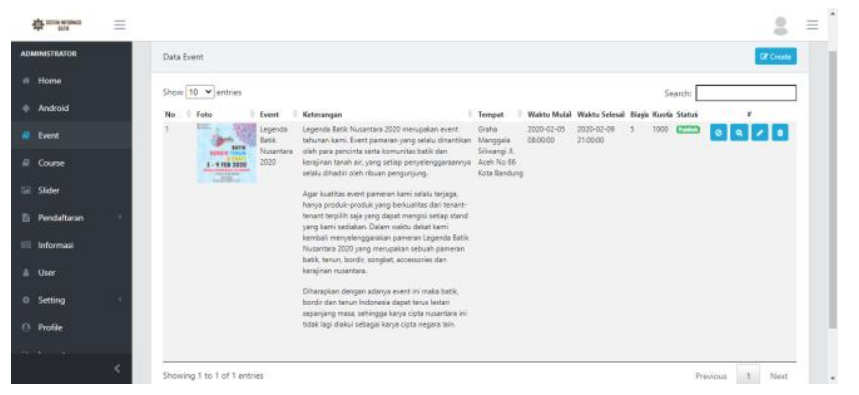

Gambar 12. Halaman Kelola Event Aplikasi NusaBatik via Website

Pada Gambar 12 merupakan tampilan Halaman Kelola Event Aplikasi NusaBatk via Website, disini admin dapat mengelola Event seperti menambah, menghapus, dan mengedit data Event.

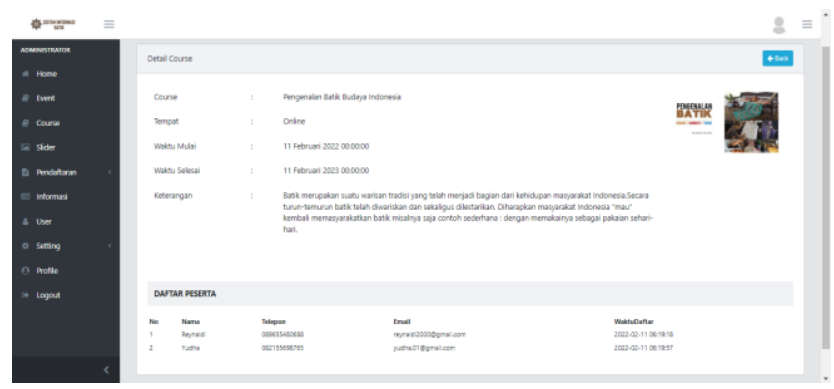

Gambar 13. Halaman Menu Course pada Admin via Website

Pada Gambar 13 merupakan tampilan Halaman Menu Course pada Admin via website. Pada halaman ini admin dapat mengetahui detail course dan berapa banyak peserta yang telah memesan course tersebut.

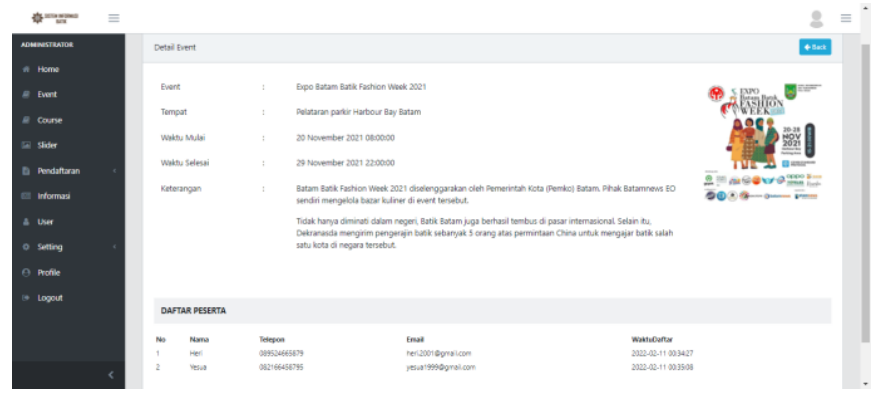

Gambar 14. Halaman Menu Data Event pada admin via Website

Pada Gambar 14 merupakan tampilan Menu Data Event pada Admin via website. Pada halaman ini admin dapat mengetahui detail Event dan berapa banyak peserta yang telah memesan event tersebut.

\section{KESIMPULAN}

Sistem Informasi aplikasi NusaBatik menjadikan salah satu jawaban terhadap proses pembelajaran pelatihan membatik luring dan daring. Sistem aplikasi ini menyajikan pembelajaran dengan metode blended learning, yang dimana awalnya pembelajaran hanya dengan cara datang langsung ke tempat membatik dan melakukan pembayaran manual menjadi pembelajaran luring dan daring dengan cara mendaftar lewat 
aplikasi dan melakukan pembayaran secara virtual yang akan memudahkan para peserta pelatihan dalam melakukan akses pendaftaran. Aplikasi NusaBatik juga menyediakan berbagai macam informasi tentang batik yang ada di indonesia, berbagai macam Course Daring, Event Daring, dan Quiz untuk melakukan tes terhadap para peserta pelatihan membatik. Kombinasi pembelajaran ini sangat di butuhkan di era modern dan di masa pandemi Covid-19 seperti ini sehingga pembelajaran ini lebih efisien.

\section{SARAN}

Adapun saran yang perlu ditambahkan untuk aplikasi berikutnya adalah :

1. Meningkatkan desain tampilan aplikasi sehingga lebih menarik

2. Mengembangkan aplikasi agar terintegrasi ke kementerian kebudayaan agar bisa digunakkan lebih meluas dan lebih optimal

3. Menambah fitur penjualan hasil membatik dengan terintegrasi pada aplikasi aplikasi e-commerce yang ada di indonesia

\section{REFERENSI}

[1] M. T. Hidayat, T. Junaidi, and M. Yakob, "Pengembangan Model Pembelajaran Blended Learning dalam Meningkatkan Pemahaman Siswa Terhadap Tradisi Lisan Aceh," J. Mimb. Ilmu, vol. 25, no. 3, pp. 401-410, 2020.

[2] I. Eny Kustiyah, "Batik Sebagai Identitas Kultural Bangsa Indonesia Di Era Globalisasi," Gema, vol. 30, no. 52, pp. 2456-2472, 2017.

[3] D. P. Andriani, U. Setiaji, and M. Habriantama, "Optimasi Parameter Ketahanan Luntur Batik Terhadap Keringat Dengan Desain Eksperimen Taguchi," vol. 36, no. 1, pp. 81-94, 2019.

[4] P. S. K and S. Pawirosumarto, "Pengaruh kualitas sistem, kualitas informasi, dan kualitas layanan terhadap penggunaan sistem e-learning di program pascasarjana universitas mercu buana," J. Manaj., vol. 21, no. 2, pp. 282-305, 2017, doi: 10.24912/jm.v21i2.237.

[5] A. Ratnasari, "Studi Pengaruh Penerapan E-Learning Terhadap Keaktifan Studi Kasus Universitas Mercu Buana Jakarta," Semin. Nas. Apl. Teknol. Inf. 2012, vol. 2012, no. Snati, pp. 15-16, 2012.

[6] Alamsyah, S. Maziyah, and S. Indrahti, "Pengenalan Dan Pelatihan Membatik Pada Remaja Di Jepara," Harmoni, vol. 4, no. 2, pp. 56-62, 2020.

[7] A. Muthmainnah and M. Suswandari, "Implementasi Station Rotation Blended Learning tehadap Motivasi Belajar dan Pendidikan Karakter Peserta Didik," Int. J. Public Devot., vol. 3, no. 2, pp. 59-64, 2020.

[8] V. Vydia, "Accelerated Learning Dalam Proses Pembelajaran Dan E-Learning Sebagai Alat Bantu Pembelajaran," J. Transform., vol. 4, no. 1, p. 1, 2006, doi: 10.26623/transformatika.v4i1.13.

[9] U. A. Chaeruman, "Merancang Model Blended Learning Designing Blended Learning Model," $J$. Teknodik, pp. 053-063, 2019, doi: 10.32550/teknodik.v17i4.577.

[10] P.- Matondang, "Blended Learning Pengembangan Modul Pembelajaran Berbasis Blended Learning Mata Pelajaran Rancang Bangun Jaringan," Pedagog. J. Ilmu Pendidik., vol. 17, no. 2, p. 13, 2018, doi: 10.24036/fip.100.v17i2.281.000-000.

[11] Setiawan, R. (2021). Metode SDLC Dalam Pengembangan Software. Retrieved 19 December 2021, from https://www.dicoding.com/blog/metodesdlc/ 